Check for updates

1 University of East Anglia, Norwich, UK

2 Tata Institute of Social Sciences, Mumbai, India

3 London School of Hygiene and Tropical Medicine, London, UK

4 International Institute for Population Sciences, Mumbai, India

5 Global Health Institute, King's College London, London, UK

6 Centre for Mental Health Law and Policy, Pune, Maharashtra, India

7 University of Aberdeen, UK

8 Department of Economics and Rural Development, Alagappa University, Tamil Nadu, India

p.lloyd-sherlock@uea.ac.uk Cite this as: BMJ 2021;373:n1464 http://dx.doi.org/10.1136/bmj.n1464 Published: 10 June 2021

\section{PANDEMIC LESSONS FROM INDIA}

\section{Pandemic lessons from India: inappropriate prioritisation for vaccination}

\author{
Peter Lloyd-Sherlock, ${ }^{1}$ Nidheesh Manee Kandiyil, ${ }^{2}$ Martin McKee, ${ }^{3}$ Arokiasamy Perianayagam, ${ }^{4}$ \\ Sridhar Venkatapuram, ${ }^{5}$ Soumitra Pathare, ${ }^{6}$ Aravinda Meera Guntupali, ${ }^{7}$ Ramesh Kumar K, ${ }^{8}$ \\ Soumitra Ghosh²
}

We welcome Reddy's editorial on covid-19 in India, ${ }^{1}$ but want to emphasise one further issue: how India's national government has inappropriately prioritised people for covid-19 vaccination.

In January 2021, India's vaccination programme began with health professionals and "frontline workers.” In March, it was extended to people aged 60 or over and those aged 45 or over with comorbidities, and in April to anyone aged 45 or over. From 1 May, vaccine entitlement was extended to all people aged 18 or over, although people under 45 must pay.

From 3 May to 5 June 2021, more first doses were administered to people under 45 than over 60 , even though at least 77 million people aged 60 remain unvaccinated. ${ }^{2}$ This is causing many deaths that could have been averted by a more targeted approach.

In practice, access to covid-19 vaccination is mainly determined by socioeconomic status, with very low coverage in rural areas and among disadvantaged urban populations. ${ }^{3}$ Indians of all ages are increasingly resorting to private purchases, and the country's minimal pension system makes this especially unaffordable for older people. No special provision has been made to facilitate vaccine access for adults with impaired mobility, and older people tend to be less familiar with the digital technology required to make a booking.

India is not alone in focusing its covid-19 vaccination on younger age groups. ${ }^{4}$ The director general of the World Health Organization said: "There is a disturbing narrative in some countries that it's OK if older people die. It's not OK ... It is important that everywhere older people are prioritised for vaccination. Those most at risk of severe disease and death from covid-19, including health workers and older people, must come first. And they must come first everywhere." ${ }^{5}$

Some Indian states have now reallocated available doses to older people. ${ }^{6}$ We urge the national government to do the same until all older people in India have received at least one dose. Its current approach to vaccination is causing huge numbers of avertable deaths and is deeply inequitable, both between age groups and within them.
Reddy KS. Pandemic lessons from India. BMJ 2021;373:n1196. doi: 10.1136/bmj.n1196 pmid: 33980588

2 Government of India, Ministry of Health and Family Welfare. Covid-19 vaccination update-day 139.2021. https://pib.gov.in/PressReleasePage.aspx?PRID=1724195

3 Vaccination in India's rural districts remains low amid covid-19 surge. Science: The Wire. 2021. https://science.thewire.in/health/vaccination-inindias-rural-districts-remains-low-amid-covid-19-surge/

4 Lloyd-Sherlock P. Muljono P, Ebrahim S. Ageism in Indonesia's national covid-19 vaccination programme. BMJ2021;372:n299. doi: 10.1136/bmj.n299. pmid: 33531349

5 Tedros Adhanom Ghebreyesus. Twitter. 6 Feb 2021. https://twitter.com/DrT edros/status/1358084910569975810

6 Jain B, Pinto R, Debroy S. 60+ in Mumbai can now walk in for 2nd dose 3 days a week. Times of India. 13 May 2021. https://timesofindia.indiatimes.com/city/mumbai/60-in-city-can-now-walk-in-for-2nd-dose-3-daysa-week/articleshow/82590158.cms

This article is made freely available for use in accordance with BMJ's website terms and conditions for the duration of the covid-19 pandemic or until otherwise determined by BMJ. You may use, download and print the article for any lawful, non-commercial purpose (including text and data mining) provided that all copyright notices and trade marks are retained. 